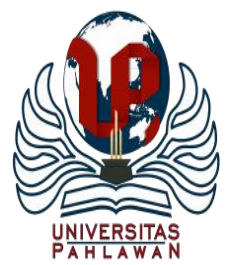

Edukatif : Jurnal Ilmu Pendidikan Volume 3 Nomor 4 Tahun 2021 Halm 2159 - 2167

EDUKATIF: JURNAL ILMU PENDIDIKAN

Research \& Learning in Education

https://edukatif.org/index.php/edukatif/index

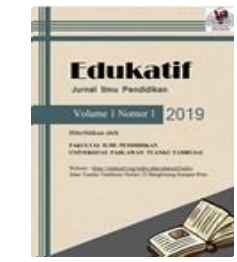

\title{
Pengaruh Pelaksanaan Layanan Informasi dengan Pembelajaran Kontekstual dalam Meningkatkan Arah Perencanaan Karier Siswa SMK
}

\author{
Tumiyem $^{1 凶}$, Syahrina Annisa ${ }^{2}$, Yudi Umara ${ }^{3}$, Bagus Aria Syahputra ${ }^{4}$ \\ Sekolah Tinggi Keguruan Ilmu Pendidikan Amal Bakti, Indonesia 1,2,3.4 \\ E-mail : tumiyem_sumatera@yahoo.com ${ }^{1}, \underline{\text { syahrinaanisa7@gmail.com }}^{2}$, yudialumara@ gmail.com ${ }^{3}$
}

\begin{abstract}
Abstrak
Salah satu upaya yang dilakukan dalam meningkatkan arah perencanaan karir mahasiswa adalah melalui layanan informasi dengan pembelajaran kontekstual. Penelitian ini bertujuan untuk mengetahui pengaruh layanan informasi dengan pembelajaran kontekstual dalam meningkatkan arah perencanaan karir siswa SMK Negeri 1 Bintang Bayu. Penelitian ini menggunakan metode kuantitatif. Jenis penelitian ini adalah Quasi Experimental dengan Nonrandomized Control Group Pretest-posttest Design. Subjek penelitian ini adalah siswa SMK Negeri 1 Bintang Bayu. Instrumen penelitian yang digunakan adalah Instrumen Perencanaan Karir Siswa Smk Negeri 1 Bintang Bayu dengan model Skala Likert, menunjukkan koefisien thitung sebesar 4,257 dengan nilai $\mathrm{P}$ sebesar 0,000. Hipotesis diterima jika P-value lebih kecil dari taraf signifikansi 0,05. Dari hasil perhitungan tersebut didapatkan P-value lebih kecil dari taraf signifikansi $0,05(0,000<0,05)$, sehingga H0 ditolak dan H1 diterima. Teknik analisis data menggunakan Independent Samples t-test dengan bantuan SPSS versi 17.00. Secara umum, hasil penelitian menunjukkan bahwa layanan informasi dengan pembelajaran kontekstual lebih efektif dalam meningkatkan arah perencanaan karir siswa SMK Negeri 1 Bintang Bayu.
\end{abstract}

Kata Kunci: Arah Perencanaan Karier, Layanan Informasi, Pembelajaran Kontekstual.

\begin{abstract}
One of the efforts made in improving the direction of student career planning is through information services with contextual learning. This study aims to determine the effect of information services with contextual learning in improving the direction of career planning for vocational students. This study uses quantitative methods. This type of research is Quasi Experimental with Nonrandomized Control Group Pretest-posttest Design. The subjects of this study were students of SMK Negeri 1 Bintang Bayu. The research instrument used is the Instrument for Career Planning for Vocational High School Students with a Likert Scale model, showing the t-count coefficient of 4.257 with a P-value of 0.000. The hypothesis is accepted if the P-value is smaller than the 0.05 significance level. From the results of these calculations, the P-value is smaller than the significance level of 0.05 (0.000 <0.05), so HO is rejected and H1 is accepted. Data were analyzed using Independent Samples t-test with the help of SPSS version 17.00. In general, research findings indicate that information services with contextual learning are more effective in improving the direction of career planning for vocational students SMK Negeri 1 Bintang Bayu.
\end{abstract}

Keywords: Career Planning Directions, Information Services, Contextual Learning.

Copyright (c) 2021 Tumiyem, Syahrina Annisa, Yudi Umara, Bagus Aria Syahputra

$\square$ Corresponding author

Email : tumiyem_sumatera@yahoo.com

DOI $\quad:$ https://doi.org/10.31004/edukatif.v3i4.1021

ISSN 2656-8063 (Media Cetak)

ISSN 2656-8071 (Media Online) 
2160 Pengaruh Pelaksanaan Layanan Informasi dengan Pembelajaran Kontekstual dalam Meningkatkan Arah Perencanaan Karier Siswa SMK- Tumiyem, Syahrina Annisa, Yudi Umara, Bagus Aria Syahputra

DOI : https://doi.org/10.31004/edukatif.v3i4.1021

\section{PENDAHULUAN}

Perjalanan karier yang dihadapi seseorang dimulai sejak mereka mendapatkan pendidikan karier di sekolah. Hal ini sesuai dengan salah satu tugas perkembangan remaja yaitu mulai memikirkan masa depan secara bersungguh-sungguh. Masa pendidikan yang siswa lewati di SMK Negeri 1 Bintang Bayu Negeri 1 Bintang Bayu akan menjadi sangat berarti dalam membina dan mematangkan persiapan pilihan pekerjaan dan menyusun rencana pekerjaan yang sesuai dengan diri masing-masing. Anak laki-laki biasanya lebih bersungguh-sungguh dalam hal pekerjaan dibandingkan dengan anak perempuan yang kebanyakan memandang pekerjaan sebagai pengisi waktu sebelum menikah. Pada usia tersebut, remaja akan belajar membedakan antara pilihan pekerjaan yang lebih disukai dengan pekerjaan yang dicita-citakan (WS Winkel dan S Hastuti, 2005). Guru yang profesional tidak hanya cukup memenuhi persyaratan administratif, melainkan bagaimana guru dapat memberikan pengertian, pemahaman, dan dapat mendorong peserta didik ke arah aktivitas secara individual terhadap ilmu yang diberikannya. Peran guru pada pembelajaran biasa guru masih mendominasi, akibatnya siswa tidak berkembang, siswa hanya akan belajar jika ada perintah oleh guru, menyelesaikan soal-soal jika ditunjuk guru. Untuk mengubah paradigma pembelajaran yang berpusat pada guru (teacher centered) menuju pembelajaran yang lebih bermakna yaitu pembelajaran yang berpusat pada siswa (student centered). Pembelajaran yang berpusat pada siswa memberikan peluang pada siswa untuk menumbuhkembangkan motivasi, kreativitas, kemampuan spasial dan melatih kemampuan berpikir kritis, siswa dilatih memecahkan permasalahan dalam realita kehidupan (Sari. D. P dan \& Amran, 2020).

Model pembelajaran yang sesuai dalam megatasi sikap peserta didik yang tidak baik yaitu model pembelajaran kontekstual yang merupakan model pembelajaran yang bertujuan membantu siswa melihat makna dalam bahan pelajaran yang dipelajari dengan cara mengamalkannya dikehidupan nyata mereka sehari hari (Irfan, 2020). Menurut (Rudi Hartono, 2013) pembelajaran kontekstual lebih menekankan proses keterlibatan siswa untuk menemukan materi belajarnya sendiri, artinya proses belajar diorientasikan padaproses pengalaman secara langsung. Pembelajaran yang berpusat pada masalah kontekstual dalam kehidupan nyata siswa dapat melatih keterampilan matematika pada kemampuan representasi matematis siswa denga cara memberikan mereka beberapa pengalaman belajar. Pengalaman belajar memfokuskan pada bagaimana merencanakan pemecahan masalah, melaksanakan rencana dengan cara mandiri, dan mengevaluasi hasil belajarnya. Pembelajaran yang berpusat pada masalah kontekstual dalam kehidupan nyata siswa dapat melatih keterampilan matematika pada kemampuan representasi matematis siswa dengan cara memberikan mereka beberapa pengalaman belajar (Ambarwati, Sutiarso, \& Noer, 2020). Pembelajaran kontekstual (Contextual Teaching and Learning) adalah konsep belajar yang membantu guru mengaitkan antara materi yang diajarkan dengan situasi dunia nyata siswa dan mendorong siswa membuat hubungan antara pengetahuan yang dimilikinya dengan penerapannya dalam kehidupan mereka sehari-hari (Erik Santoso, 2017). Selvianiresa \& Prabawanto (Musyafa et al., 2020) Pendekatan kontekstual atau Contextual Teaching and Learning (CTL) sering bersentuhan dengan siswa, yaitu suatu pendekatan yang menghubungkan dengan kehidupan sehari-hari.

Menurut (Ramlah, 2018) Bimbingan konseling merupakan bantuan yang diberikan kepada peserta didik baik individu/ kelompok agar peserta didik dapat mandiri, berkembang secara optimal dalam hubungan pribadi, sosial, belajar, karier, lewat berbagai jenis layanan dan kegiatan pendukung atas dasar norma-norma yang berlaku. (Musdalifah, 2021) menyatakan salah satu aplikasi pendukung lainnya yang juga sangat membantu proses berjalannya konseling adalah aplikasi cyber counseling (konseling berbasis dunia maya) adalah layanan konseling profesional yang melibatkan konselor dan konseli melalui media video conference, yang memungkinkan bertatap muka secara online dari layar monitor komputer/ smart phone tanpa menuntut kehadiran kedua belah pihak secara fisik serta dapat dilakukan kapan dan dimana saja. Sejalan dengan (Firda \& Atikah, 2020) menyatakan salah satu aplikasi pendukung lainnya yang juga sangat membantu proses 
2161 Pengaruh Pelaksanaan Layanan Informasi dengan Pembelajaran Kontekstual dalam Meningkatkan Arah Perencanaan Karier Siswa SMK- Tumiyem, Syahrina Annisa, Yudi Umara, Bagus Aria Syahputra

DOI : https://doi.org/10.31004/edukatif.v3i4.1021

berjalannya konseling adalah aplikasi cyber counseling (konseling berbasis dunia maya) adalah layanan konseling profesional yang melibatkan konselor dan konseli melalui media video conference, yang memungkinkan bertatap muka secara online dari layar monitor komputer/ smartphone tanpa menuntut kehadiran kedua belah pihak secara fisik serta dapat dilakukan kapan dan dimana saja. Tujuan bimbingan konseling yaitu memberikan bantuan kepada siswa dalam mengembangkan potensinya secara optimal .

Keberhasilan pelayanan bimbingan dan konseling di sekolah tidak mungkin dapat tercapai dengan baik, apabila pelaksanaan bimbingan dan konseling tidak dikelola dan diprogram secara baik. Pengelolaan pelayanan bimbingan dan konseling di sekolah merupakan suatu hasil yang esensial, apabila para pengelola dan pelaksana pendidikan menginginkan setiap siswa berkembang secara optimal, terutama program pengembangan karir siswa SMK. Di samping itu keterlaksanaan dari program bimbingan dan konseling karir di sekolah tidak dapat dipisahkan dari kemampuan guru BK untuk menyusun program kerja yang jelas, kemampuan untuk membina kerjasama yang baik dengan personil sekolah lainnnya. Setiap layanan yang dikerjakan membutuhkan pengelolaan dan perencanaan yang matang. Perencanaan yang matang tersebut dituangkan dalam sebuah program yang rasional, objektif sesuai dengan situasi dan kondisi, dan menjamin terpenuhinya berbagai kebutuhan. Program pelayanan bimbingan dan konseling karir direncanakan berdasarkan hasil analisis kebutuhan yang dirasakan oleh siswa asuh dan seluruh siswa dan pihak-pihak yang sangat berkepentingan dengan perkembangan siswa secara optimal (Prayitno \& Amti. E, 2015). Dalam penelitian ini perencanaan program bimbingan dan konseling ditujukan untuk upaya membantu meningkatkan motivasi belajar siswa SMK yang memiliki motivasi belajar rendah dan juga lebih memaksimalkan motivasi belajar siswa SMK yang telah memiliki motivasi belajar yang bagus. Menurut Fatur Rahman (Restu, 2015) Tujuan utama layanan bimbingan dan konseling di sekolah adalah memberikan dukungan pada pencapaian kematangan kepribadian, keterampilan sosial, kemampuan akademik, dan bermuara pada terbentuknya kematangan karir individual yang diharapkan dapat bermanfaat di masa yang akan datang. Maka peneliti tertarik melakukan penelitian tentang pengaruh pemberian layanan bimbingan dan konseling terhadap komunikasi interpersonal siswa kelas x smk putra jaya jabal rahmah tahun pelajaran 2020/2021.

Perspektif gender tingkat motivasi antara laki-laki dan perempuan cenderung berbeda. Laki-laki dan perempuan memiliki nilai (value) yang lebih besar atau lebih kecil dalam berbagai bidang akademis, siswa laki-laki dan perempuan memiliki keinginan belajar sendiri secara lebih khusus, keinginan belajar antara siswa yang satu dapat sama atau berbeda dari keinginan belajar siswa yang lain (Ormrod, 2008). Adanya perbedaan itu antara lain disebabkan motivasi belajar yang dimiliki masing-masing siswa tidaklah sama. Berdasarkan perumusan masalah di atas, maka secara umum tujuan penelitian ini adalah untuk mengetahui efektivitas layanan informasi dengan pembelajaran kontekstual dalam meningkatkan arah perencanaan karier siswa SMK Negeri 1 Bintang Bayu. Adapun yang menjadi tujuan khusus dalam penelitian ini adalah untuk mendeskripsikan perbedaan arah perencanaan karier kelompok eksperimen yang diberi layanan informasi dengan pembelajaran kontekstual dengan kelompok kontrol yang diberi layanan informasi dengan teknik ceramah dan tanya jawab.

\section{METODE PENELITIAN}

Penelitian ini merupakan penelitian kuantitatif dengan metode penelitian eksperimen menggunakan desain Quasi Experimental. Bentuk Quasi Experimental yang digunakan dalam penelitian ini adalah Nonrandomized Control Group Pretest-posttest Design. Menurut (Sugiyono, 2014) desain ini hampir sama dengan Pretest-posttest Control Group, hanya saja pada desain ini kelompok eksperimen maupun kelompok kontrol tidak dipilih secara random. Instrumen yang telah dibuat oleh peneliti kemudian ditimbang oleh dosen ahli dan selanjutnya diujicobakan sebelum dipergunakan sebagai pengumpul data. Uji coba ini untuk mengukur validitas dan reliabilitas instrumen. 
2162 Pengaruh Pelaksanaan Layanan Informasi dengan Pembelajaran Kontekstual dalam Meningkatkan Arah Perencanaan Karier Siswa SMK - Tumiyem, Syahrina Annisa, Yudi Umara, Bagus Aria Syahputra

DOI : https://doi.org/10.31004/edukatif.v3i4.1021

Setelah instrumen memperoleh hasil expert judgement dan telah diperbaiki, maka dilakukan uji coba instrumen penelitian untuk mengukur tingkat kelayakan instrumen (valid dan reliabel), dengan mengadministrasikan instrumen kepada siswa di luar subjek penelitian. Uji coba instrumen dilaksanakan pada 30 siswa kelas X SMK Negri 1 Bintang Bayu . Untuk mengetahui validitas instrumen digunakan analisis faktor yaitu mengkorelasikan skor item instrumen dengan skor total. Adapun rumus yang digunakan adalah Product Moment, dengan rumus berikut ini.

$$
\mathrm{r}_{\mathrm{xy}}=\frac{\mathrm{N} \sum \mathrm{XY}-\left(\sum \mathrm{X}\right)\left(\sum \mathrm{Y}\right)}{\sqrt{\left[\mathrm{N} \sum \mathrm{X}^{2}-\left(\sum \mathrm{X}\right)^{2}\right]\left[\mathrm{N} \sum \mathrm{Y}^{2}-\left(\sum \mathrm{Y}\right)^{2}\right]}}
$$

Keterangan:

$\mathrm{r}_{\mathrm{xy}}$ : angka indeks korelasi $\mathrm{r}$ product moment (variabel $\mathrm{x}$ dan $\mathrm{y}$ )

$\mathrm{N}$ : jumlah responden

$\sum X Y$ : jumlah perkalian skor item dan skor total

$\sum X$ : jumlah seluruh skor $\mathrm{X}$

$\sum Y$ : jumlah seluruh skor $\mathrm{Y}$

$\sum X^{2}$ : jumlah kuadrat skor $X$

$\sum \mathrm{Y}^{2}$ : jumlah kuadrat skor $\mathrm{Y}$

Alat ukur dikatakan reliabel, apabila alat ukur itu dicobakan kepada objek atau subjek yang sama secara berulang-ulang, maka hasilnya akan tetap sama, konsisten, stabil, atau relatif sama.Untuk mencari tingkat kepercayaan atau menentukan tingkat reliabilitas dari seluruh alat ukur (instrumen penelitian) dalam penelitian ini dilakukan dengan menggunakan rumus Alpha Cronbach berikut ini.

Keterangan:

$$
\mathrm{r}_{\mathrm{tt}}=\left[\frac{\mathrm{k}}{\mathrm{k}-1}\right]\left[1-\frac{\sum \sigma_{\mathrm{i}}^{2}}{\sigma_{\mathrm{t}}^{2}}\right]
$$

$\mathrm{r}_{\mathrm{tt}} \quad$ : reliabilitas instrumen

$\mathrm{k} \quad$ : jumlah butir soal bagian

$\sigma_{\mathrm{i}}^{2} \quad$ : jumlah varian butir soal

$\sigma_{\mathrm{t}}^{2} \quad$ :varian skor total

Analisis data merupakan salah satu langkah yang sangat penting dalam kegiatan penelitian. Data yang terkumpul lalu dianalisis untuk membuktikan hipotesis dan menarik kesimpulan tentang masalah yang akan diteliti dengan menggunakan statistik parametrik.

Deskripsi Data. Kondisi arah perencanaan karier siswa SMK Negeri 1 Bintang Bayu dideskripsikan melalui norma kategori yang diklasifikasikan dengan kriteria sangat tinggi, tinggi, sedang, rendah, dan sangat rendah. Individu dalam kelompok-kelompok terpisah secara berjenjang menurut suatu kontinum atribut yang diukur. Untuk menghitung rentang data atau interval rumus yang dapat digunakan adalah sebagai berikut.

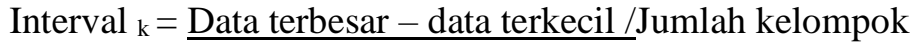

Perhitungan dalam menentukan rentangan skor atau interval skor dalam penelitian ini dilakukan sebagai berikut.

Pengujian Persyaratan Analisis. Pengujian hipotesis dalam penelitian ini menggunakan uji $\mathrm{t}$ atau $t$ test. Persyaratan yang harus dipenuhi untuk menggunakan uji t atau $t$ test adalah data berdistribusi normal dan homogen. Untuk itu perlu dilakukan pengujian normalitas dan homogenitas terhadap data yang telah diperoleh

a. Uji Normalitas Data

Pengujian normalitas dilakukan untuk mengetahui apakah data berasal dari populasi yang berdistribusi normal atau berada dalam sebaran normal. Salah satu teknik yang dapat digunakan untuk melakukan 
2163 Pengaruh Pelaksanaan Layanan Informasi dengan Pembelajaran Kontekstual dalam Meningkatkan Arah Perencanaan Karier Siswa SMK- Tumiyem, Syahrina Annisa, Yudi Umara, Bagus Aria Syahputra

DOI : https://doi.org/10.31004/edukatif.v3i4.1021

pengujian normalitas adalah dengan uji Kolmogorov-Smirnov. Untuk menyatakan apakah data berdistribusi normal atau tidak, dapat membandingkan koefisien Asymp.Sig atau $P$-value dengan taraf signifikansi 0.05 .

Data dikatakan berdistribusi normal apabila koefisien $P$-value lebih besar dari taraf signifikansi 0.05 . Sebaliknya, apabila koefisien $P$-value lebih kecil dari taraf signifikansi 0.05 , memiliki makna bahwa data berasal dari populasi yang berdistribusi tidak normal.

b. Uji Homogenitas

Data dikatakan homogen apabila koefisien $P$-value lebih besar dari taraf signifikansi 0.05 . Sebaliknya, apabila koefisien $P$-value lebih kecil dari taraf signifikansi 0.05 , memiliki makna bahwa data berasal dari populasi yang tidak homogen.

c. Pengujian Hipotesis Penelitian.

Data penelitian untuk meningkatkan variabel arah perencanaan karier siswa mempunyai karakteristik sebagai berikut: (1) data interval, (2) data berdistribusi normal, (3) berpasangan (pretest-posttest), (4) sampelnya besar (subjek penelitian), dan (5) menggunakan penelitian eksperimen atau perlakuan. Berdasarkan karakteristik tersebut, maka teknik analisis data yang digunakan adalah statistik parametrik. Oleh karena itu, metode analisis data yang dilakukan dalam penelitian ini adalah dengan menggunakan teknik Independent Sample t-test. Teknik ini digunakan untuk melihat perbedaan arah perencanaan karier kelompok eksperimen dengan kelompok kontrol sesudah diberi perlakuan. Untuk menganalisis hasil penelitian peneliti menggunakan bantuan program SPSS versi 17.00.

\section{HASIL DAN PEMBAHASAN PENELITIAN}

\section{Deskripsi Data Pretest dan Posttest Arah Perencanaan Karier Siswa Smk Negeri 1 Bintang Bayu Kelompok Eksperimen}

Data penelitian pada kelompok eksperimen diperoleh berdasarkan instrumen arah perencanaan karier yang telah diberikan kepada 30 orang siswa kelompok eksperimen sebelum perlakuan (pretest) dan sesudah perlakuan (posttest). Berikut disajikan skor masing-masing arah perencanaan karier siswa SMK Negeri 1 Bintang Bayu pada kelompok eksperimen sebelum dan sesudah diberikan perlakuan

Perencanaan karier siswa SMK Negeri 1 Bintang Bayu kelompok eksperimen mengalami perubahan atau peningkatan sesudah diberikan layanan informasi dengan pembelajaran kontekstual. Sebelum diberikan layanan informasi dengan pembelajaran kontekstual, rata-rata skor pretest sebesar 183 dan berada pada kategori sedang. Selanjutnya, sesudah diberikan layanan informasi dengan pembelajaran kontekstual rata-rata skor posttest meningkat menjadi sebesar 218 dan berada pada kategori tinggi. Perbedaan frekuensi kondisi kelompok eksperimen dari hasil pretest dan posttest tentang arah perencanaan karier siswa SMK Negeri 1 Bintang Bayu dapat dilihat pada tabel berikut ini.

Tabel 1. Distribusi Frekuensi Pretest dan Posttest Arah Perencanaan Karier Siswa Kelompok Eksperimen

\begin{tabular}{cccccc}
\hline Interval & Kategori & \multicolumn{2}{c}{ Pretest } & \multicolumn{2}{c}{ Posttest } \\
\cline { 3 - 6 } & & Frekuensi & $\%$ & Frekuensi & $\%$ \\
\hline $\mathbf{2 3 5}$ & Sangat Tinggi & 0 & 0 & 12 & 40 \\
\hline $\mathbf{1 9 0 - 2 3 4}$ & Tinggi & 10 & 33.33 & 18 & 60 \\
\hline $\mathbf{1 4 5 - 1 8 9}$ & Sedang & 20 & 66.66 & 0 & 10 \\
\hline $\mathbf{1 0 0 - 1 4 4}$ & Rendah & 0 & 10 & 0 & 0 \\
\hline $\mathbf{5 9 9}$ & Sangat Rendah & 0 & 0 & 0 & 0
\end{tabular}


2164 Pengaruh Pelaksanaan Layanan Informasi dengan Pembelajaran Kontekstual dalam Meningkatkan Arah Perencanaan Karier Siswa SMK- Tumiyem, Syahrina Annisa, Yudi Umara, Bagus Aria Syahputra

DOI : https://doi.org/10.31004/edukatif.v3i4.1021

$\begin{array}{lllll}\text { Jumlah } & 30 & 100 & 30 & 100\end{array}$

Berdasarkan Tabel 1 dapat diketahui bahwa terdapat perbedaan arah perencanaan karier Siswa SMK Negeri 1 Bintang Bayu pada kelompok eksperimen sebelum dan sesudah mendapat perlakuan layanan informasi dengan pembelajaran kontekstual. Pada saat pretest, arah perencanaan karier 10 orang siswa berada pada kategori tinggi dengan persentase sebesar $33.33 \%$ dan 20 orang siswa berada pada kategori sedang dengan persentase sebesar $66.66 \%$. Setelah diberikan perlakuan terjadi perubahan di mana dapat dilihat dari hasil posttest, sebanyak 12 orang siswa berada dalam kategori sangat tinggi dengan persentase sebesar $40 \%$, dan 18 orang siswa berada dalam kategori tinggi dengan persentase sebesar $60 \%$.

\section{Deskripsi Data Pretest dan Posttest Arah Perencanaan Karier Siswa SMK Negeri 1 Bintang Bayu} Kelompok Kontrol

Data penelitian pada kelompok kontrol diperoleh berdasarkan instrumen arah perencanaan karier yang telah diberikan kepada 33 orang siswa kelompok eksperimen sebelum perlakuan (pretest) dan sesudah perlakuan (posttest). Berikut di sajikan skor masing-masing arah perencanaan karier siswa SMK Negeri 1 Bintang Bayu pada kelompok kontrol sebelum dan sesudah diberikan perlakuan.

Perbedaan frekuensi kondisi kelompok kontrol dari hasil pretest dan posttest tentang arah perencanaan karier siswa SMK Negeri 1 Bintang Bayu dapat dilihat pada tabel berikut ini.

Tabel 2.Distribusi Frekuensi Pretest dan Posttest Arah Perencanaan Karier Siswa Kelompok Kontrol

\begin{tabular}{cccccc}
\hline Interval & Kategori & \multicolumn{2}{c}{ Pretest } & \multicolumn{3}{c}{ Posttest } \\
\cline { 3 - 6 } & & Frekuensi & $\%$ & Frekuensi & $\%$ \\
$\mathbf{2} 235$ & Sangat Tinggi & 0 & 0 & 0 & 0 \\
\hline $\mathbf{1 9 0 - 2 3 4}$ & Tinggi & 10 & 30.30 & 30 & 90.90 \\
\hline $\mathbf{1 4 5 - 1 8 9}$ & Sedang & 23 & 69.69 & 3 & 9.09 \\
\hline $\mathbf{1 0 0 - 1 4 4}$ & Rendah & 0 & 10 & 0 & 0 \\
\hline$\leq \mathbf{9 9}$ & Sangat Rendah & 0 & 0 & 0 & 0 \\
\hline & & 33 & 100 & 33 & 100 \\
\hline
\end{tabular}

Berdasarkan Tabel 2 di atas, dapat diketahui bahwa terdapat perbedaan arah perencanaan karier siswa SMK Negeri 1 Bintang Bayu pada kelompok kontrol sebelum dan sesudah mendapat perlakuan layanan informasi konvensional. Pada saat pretest, arah perencanaan karier 10 orang siswa berada pada kategori tinggi dengan persentase sebesar $30.30 \%$ dan 23 orang siswa berada pada kategori sedang dengan persentase sebesar 69.69\%. Setelah diberikan perlakuan terjadi perubahan dimana dapat dilihat dari hasil posttest, sebanyak 30 orang siswa berada dalam kategori tinggi dengan persentase sebesar $90.90 \%$, dan 3 orang siswa berada dalam kategori sedang dengan persentase sebesar $9.09 \%$.

Berdasarkan Tabel 5.8, terlihat 33 orang anggota kelompok kontrol yang dilibatkan dalam perhitungan, mengalami peningkatan skor dari pretest dan posttest atau mengalami perubahan setelah diberikan layanan informasi konvensional. Untuk melihat kondisi masing-masing arah perencanaan karier siswa dari kelompok pretest dan posttest dapat dijelaskan pada gambar di bawah ini. 


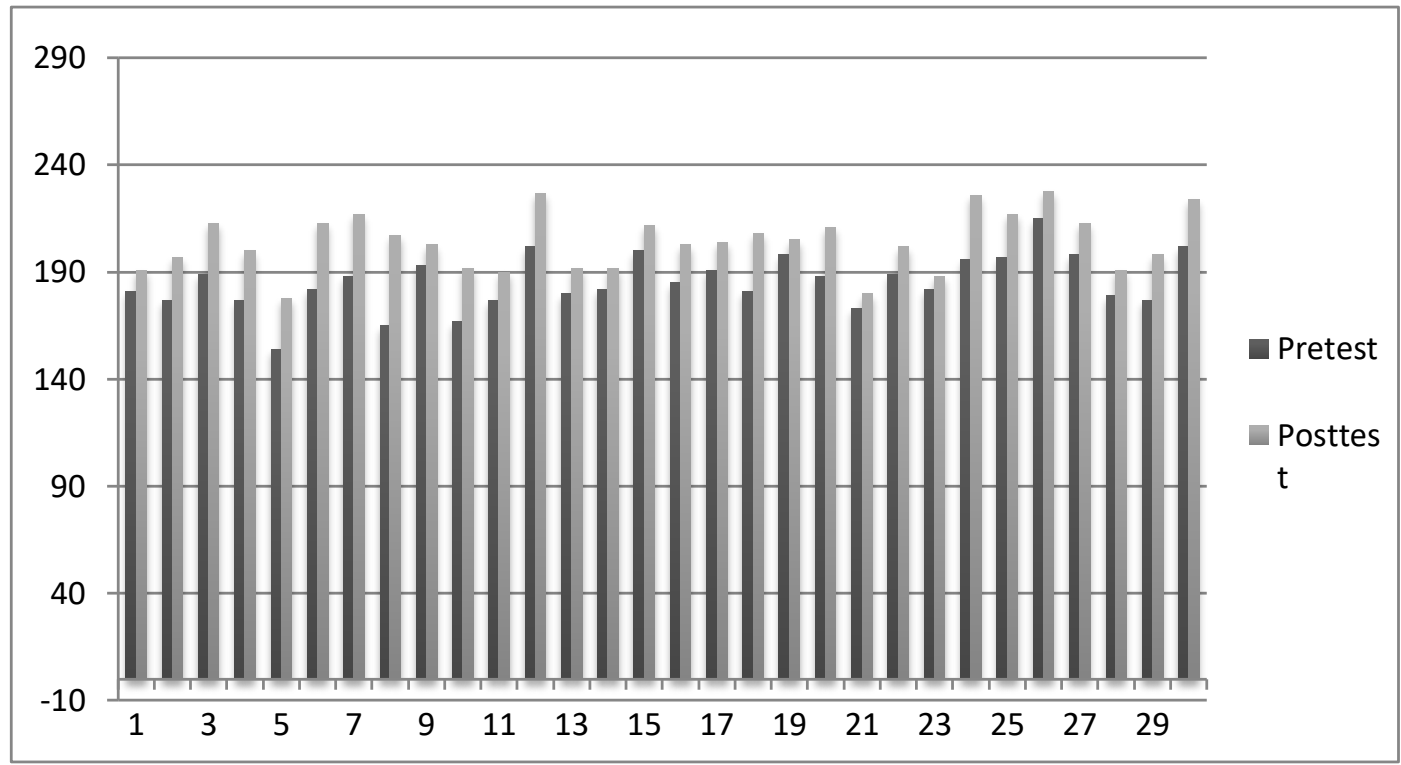

Gambar 1. Diagram Hasil Pretest dan Posttest Arah Perencanaan Karier Siswa SMK NEGERI 1 BINTANG BAYU Kelompok Kontrol

Berdasarkan Gambar 1, dapat diketahui bahwa terdapat perbedaan arah perencanaan karier siswa SMK Negeri 1 Bintang Bayu sebelum dan sesudah diberi perlakuan layanan informasi konvensional. Sebanyak 33 orang siswa mengalami peningkatan terhadap arah perencanaan karier sesudah diberikan perlakuan.

Penelitian yang dilakukan (Sriati, 2020) Setelah dilakukan proses siklus ke-1 nilai rata-rata siswa meningkat menjadi 78.67. Dari hasil tersebut dapat dilihat bahwa terjadi peningkatan dalam keterampilan siswa yang sudah dapat mencapai TPM. Setelah dilakukan siklus ke-2 nilai rata-rata siswa juga mengalami peningkatan yaitu menjadi 83.33. Dapat disimpulkan bahwa model pembelajaran kontekstual dapat meningkatkan keterampilan menulis siswa. Melalui pendekatan Contextual Teaching and Learning (CTL) pembelajaran dikaitkan dengan kehidupan sehari-hari siswa yang mampu membawa perubahan ke arah yang lebih baik, lebih memberdayakan siswa dan tidak mengharuskan siswa menghafal fakta-fakta, tetapi lebih mendorong siswa untuk membangun sendiri pengetahuannya melalui interaksi dengan objek, pengetahuan awal yang mereka miliki, pengalaman, dan lingkungan siswa (Syaparuddin, 2020).

\section{KESIMPULAN}

Dari hasil penelitian diatas, kelompok eksperimen mengalami peningkatan arah perencanaan karier yang lebih tinggi dibandingkan dengan kelompok kontrol. Perbedaan arah perencanaan karier siswa SMK Negeri 1 Bintang Bayu terjadi karena adanya perbedaan perlakuan yang diterima oleh masing-masing kelompok, walaupun materi dan banyaknya perlakuan yang diberikan sama-sama berjumlah 2 kali. Kelompok eksperimen diberikan perlakuan layanan informasi dengan pembelajaran kontekstual, sementara kelompok kontrol diberikan perlakuan layanan informasi dengan teknik ceramah dan tanya jawab. Pada kelompok eksperimen pemberian layanan informasi dengan pembelajaran kontekstual dilakukan dengan membagi kelas menjadi beberapa kelompok. Pembagian kelompok dilakukan untuk membahas materi yang telah ditentukan, sehingga tugas yang diberikan dapat dipecahkan secara diskusi kelompok. Kemudian, hasil diskusi kelompok tersebut dipresentasikan di depan kelas oleh perwakilan masing-masing kelompok. Setiap kelompok yang dibentuk mengalami perubahan pada setiap pertemuan agar kelompok menjadi bervariasi dan setiap siswa memiliki kesempatan yang sama untuk menjadi perwakilan kelompok. 
2166 Pengaruh Pelaksanaan Layanan Informasi dengan Pembelajaran Kontekstual dalam Meningkatkan Arah Perencanaan Karier Siswa SMK- Tumiyem, Syahrina Annisa, Yudi Umara, Bagus Aria Syahputra DOI : https://doi.org/10.31004/edukatif.v3i4.1021

\section{UCAPAN TERIMA KASIH}

Dalam kesempatan ini peneliti mengucapkan terima kasih sebanyak-banyaknya kepada:

1. Ketua STKIP AMAL BAKTI yang telah memberikan perizinan

2. Kepala Sekolah SMK Negeri 1 Bintang Bayu dan Guru kelas X yang telah memberikan izin dan membantu jalannya penelitian

3. Siswa kelas X SMK Negeri 1 Bintang Bayu yang telah antusias dalam menjalankan pembelajaran yang dilakukan peneliti

\section{DAFTAR PUSTAKA}

Abkin. (2013). Panduan Bimbingan Dan Konseling: Pelayanan Arah Peminatan Peserta Didik.

Ambarwati, E. P., Sutiarso, S., \& Noer, S. H. (2020). Pengembangan Strategi Pembelajaran Kontekstual Untuk Meningkatkan Kemampuan Representasi Matematis Siswa. Jurnal Cendekia: Jurnal Pendidikan Matematika, 4(2), 1011-1022. Https://Doi.Org/10.31004/Cendekia.V4i2.343

Erik Santoso. (2017). Penggunaan Model Pembelajaran Kontekstual Untuk Meningkatkan Kemampuan Pemahaman Matematika Siswa Sekolah Dasar. Jurnal Cakrawala Pendas, 3(16-29).

Firda, E., \& Atikah, J. F. (2020). Layanan Bimbingan Dan Konseling Ditengah Pandemi Covid-19. Pd Abkin Jatim Open Journal System, 1(1), 490-494.

Irfan, M. (2020). Implementasi Model Pembelajaran Kontekstual Pada Pembelajaran Pendidikan Agama Islam Dalam Meningkatkan Akhlak Peserta Didik. Qathrunâ, $7(2), \quad 83$. Https://Doi.Org/10.32678/Qathruna.V7i2.3535

Musdalifah, A. (2021). Media Daring Layanan Bk Di Masa Pandemi Covid-19. Ristekdik: Jurnal Bimbingan Dan Konseling, 6(1), 109. Https://Doi.Org/10.31604/Ristekdik.2021.V6i1.109-113

Musyafa, M., Warsali, W., Milah, C. S., Aliyudin, A., Supianti, I. I., \& Amam, A. (2020). Pendekatan Contextual Teaching And Learning (Ctl) Untuk Meningkatkan Pemahaman Matematik Siswa Pada Materi Aritmatika Sosial. Teorema: Teori Dan Riset Matematika, 5(1), 69. Https://Doi.Org/10.25157/Teorema.V5i1.3263

Ormrod, E. J. (2008). Psikologi Pendidikan. Terjemahan Oleh Amitya Kumara. Jakarta: Erlangga.

Osipow, S. . (1983). Theories Of Career Development (Third Edit). New Jersey: Prentice-Hall, Inc.

Prayitno \& Amti. E. (2015). Dasar-Dasar Bimbingan Dan Konseling (3rd Ed.). Jakarta: Rineka Cipta.

Ramlah. (2018). Pentingnya Layanan Bimbingan Konseling Bagi Peserta Didik. Al-Mau'izhah, l(September), $70-76$.

Restu, V. (2015). Pengembangan Program Layanan Pendidikan Inklusif. Repository.Upi.Edu, 1-8.

Rudi Hartono. (2013). Ragam Model Mengajar Yang Mudah Diterima Murid. Yogyakarta: Diva Press.

Sari. D. P Dan, \& Amran. (2020). Penerapan Pembelajaran Kooperatif Tipe Jigsaw Terhadap Keyakinan Diri (Self-Efficacy) Siswa. Al - Irsyad: Jurnal Pendidikan Dan Konseling, 10(2), 213-222.

Sriati, N. W. (2020). Penerapan Model Pembelajaran Kontekstual Pada Mata Pelajaran Menulis Di Kelas Ix. Bahasa Sieni Dan Pengajarannya, 15(1), 1-9. Https://Doi.Org/10.23887/Prasi.V15i01.25454

Sugiyono. (2014). Memahami Penelitian Kualitatif (10th Ed.). Bandung.

Syaparuddin, S. (2020). Pendekatan Contextual Teaching And Learning Pada Guru Terhadap Siswa Dalam Kehidupan Bermasyarakat. Jurnal Edukasi Non Formal, 1(2).

Tohirin. (2011). Bimbingan Dan Konseling Di Sekolah Dan Madrasah Berbasis Integrasi. Jakarta: Raja Grafindo. 
2167 Pengaruh Pelaksanaan Layanan Informasi dengan Pembelajaran Kontekstual dalam Meningkatkan Arah Perencanaan Karier Siswa SMK- Tumiyem, Syahrina Annisa, Yudi Umara, Bagus Aria Syahputra DOI : https://doi.org/10.31004/edukatif.v3i4.1021

Ws Winkel Dan S Hastuti. (2005). Bimbingan Dan Konseling Di Institusi Pendidikan (Edisi Revisi). Jakarta: Gramedia.

Zen, M. (2012). Faktor-Faktor Dominan Yang Berpengaruh Dalam Perencanaan Arah Karier (Studi Pada Siswa Sma Negeri Kota Pariaman). Disertasi Tidak Diterbitkan. Padang Program Studi Doktor Ilmu Pendidikan Pps Unp Padang. 